\title{
The Most Frequent Agronomic Practices Used by the Coconut Farmers in the "Coconut Triangle" of Sri Lanka
}

\author{
Baptiste Legrand $^{1}$, Angélique Perraut ${ }^{1}$, Chaminda Herath ${ }^{2}$, Rusitha Wijekoon ${ }^{2}$ and Lalith Perera ${ }^{2 *}$
}

\begin{abstract}
The study was carried out to identify the most frequently practiced cultural practices by coconut growers in the main coconut growing area termed as "Coconut Triangle", among a set of technical practices recommended by the Coconut Research Institute of Sri Lanka (CRISL). The objective was also to analyse the impact of these practices to the yield and to analyse the effects of the information sources to the growers to enhance the farmers skills. The study was carried out between June 2018 and August 2018. For the data collection, a questionnaire developed by CRISL was used and 62 growers were randomly selected. All the answers were gathered in a table file. Then, the data were analysed using tabular analysis and the software SPSS. The study reveals that most of the growers are having intercrops between the coconut trees, in large or very small scale even if the yield is lowand needs more space. For the soil moisture conservation around the coconut palm, the majority of the growers use the simple and low-cost technique; mulching around the coconut palms. However, $30.1 \%$ of the growers were found to not use any technique to improve the soil moisture even when the drought is a frequent event in the country, but this more valid for small scale growers. To improve their yield, majority of the growers preferred and used CRISL recommended coconut fertilizer mixture (Adult Palm Mixture or APM) over the other commercially available fertilizer mixtures. Finally, the study shows that farmers with large estates are the most involved to follow training programs and apply the advices given by the CRISL.
\end{abstract}

Key words: Agronomic practices/ moisture conservation/ mulching.

\section{Introduction}

Coconut (Cocos nucifera) is a perennial tree crop. Sri Lanka is one of the main coconuts producing country behind Indonesia, Philippines, India and Brazil, with a production of around 2.5 to 2.8 million nuts per year from the coconut cultivated area of 443,538 hectares (Department of Census and Statistics, 2018). The coconut cultivation is focused in the "Coconut Triangle" which gathers Puttalam, Kurunegala and Gampaha districts. About $70 \%$ of the national coconut yield comes from these three districts (Pathmeswaran et al., 2018). In the world market, Sri Lanka is very popular for desiccated coconuts and brown fibers.

The coconut, which is referred to as the "Tree of life", is one of the major plantation crops in Sri Lanka which accounts for approximately $21 \%$ of all agricultural produce in Sri Lanka. It contributes significantly to the economy of the country with fulfilling local requirements, and also earning foreign exchange as well. Coconut is very important for local people because it provides about $22 \%$ of the per capita intake in the diet. Besides, the coconut industry provides employment to more than 1 million people. They are involved in the production, processing and trading sectors of the coconut industry (Herath, et al., 2015).

\footnotetext{
${ }^{1}$ Higher National Engineering School of Agronomy and Food Science, University of Lorraine, France.

${ }^{2}$ Coconut Research Institute, Sri Lanka.

"Corresponding Author: lalithperera1234@yahoo.com
} 
With the Coconut Development Authority and the Coconut Cultivation Board, the Coconut Research Institute (CRISL) is one of the three major Government Institutions that are responsible for coconut production in the country. The CRISL was founded in 1929 and it is the first institute established in the world entirely dedicated to develop coconut tree crop. The CRI has some estates around the country which are used for mass production of improved coconut varieties and as substations for research purposes. It provides to coconut grower advices regarding to agricultural practices to improve their coconut yield (About the Coconut Research Institute, Published by Technology Transfer Division, CRISL, 2018).

The study was carried out to understand the most frequent practices that are used among a set of technical practices proposed by the Coconut Research Institute to the farmers. The objective was also to analyse the impact of these practices to the yield and to analyse the effects of the information sources to enhance the farmers skills.

\section{Methodology}

The study was carried out between June 2018 and August 2018. The data were collected by using different methods. First of all, a questionnaire with forty questions was established. Then, the data were collected from randomly selected growers mostly from major coconut growing districts in the coconut triangle; Kurunegala, Gampaha and Puttalam, through face to face interviews in their fields. In addition, another set of data were collected from some growers who attended training programs organised for the coconut growers by the CRISL and from those who visited the Coconut Technology Park of the CRISL. The Technology Park was established in 2009 to allow the farmers to witness recommended cultural practices to resolve their problems and to observe the technical recommendations that are applied in the coconut field (About the Coconut Research Institute, Published by Technology Transfer Division, CRI, 2018).

The farmers were interviewed to identify the most frequent cultural practices that are used by them and to identify a potential impact of these practices to their yield. Simple random sampling technique was adopted to collect the data. Each farmer was personally interviewed. The total sample size was 62 .

In the questionnaire, the questions concerning the impact of agricultural practices on the yield were measured in five points Likert scale where response namely "Strongly disagree", "Disagree", "Neutral", "Agree" and "Strongly agree" with corresponding score of 1,2,3,4 and 5. All the answers were gathered in a table file. The data were analysed using Tabular analysis and the software SPSS, Version 17.0.

\section{Results and Discussion}

\section{Demographic characteristics}

The sample group of this survey was made up of people above 50 years old in majority. $19 \%$ of the farmers were between 40 and 49 years old, $15 \%$ were between 30 and 39 years old and a few farmers $(6 \%)$ were between 18 and 29 years old. (Figure 1 )

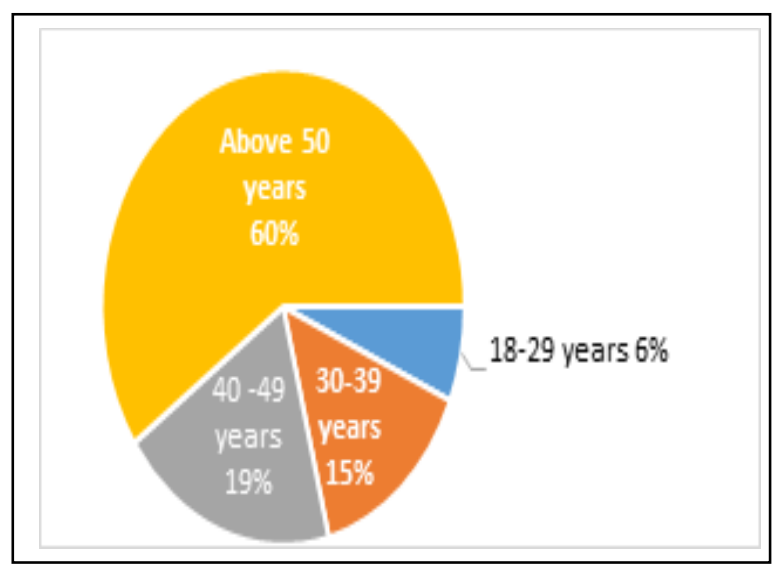

Figure 1. Ages of the population $(\mathrm{N}=62)$

All farmers have attended school and received at least primary education. Among them, 26\% had O/L level, 37\% had $\mathrm{A} / \mathrm{L}$ level and $32 \%$ received a higher level of education. The majority of them $(85.5 \%)$ were married. Concerning the farm, $68 \%$ of the respondents belonged to less than 5 acres category (Table 1). 
Table 1. Farm size $(\mathrm{N}=59)$

\begin{tabular}{|c|c|}
\hline Surface (acress) & Number \\
\hline$] 0 ; 5[$ & $68 \%$ \\
\hline$[5 ; 10[$ & $8 \%$ \\
\hline$[10 ; 15[$ & $5 \%$ \\
\hline$[15 ; 20[$ & $5 \%$ \\
\hline Above 20 & $14 \$$ \\
\hline
\end{tabular}

The smallest estate measured 0.10 acres while the biggest was 385 acres.Average yield was 74.1 nuts/tree/year.

The most frequently practices used by the farmers

One of the purposes of the questionnaire was to identify what are the most frequently practice recommended cultural practices used by growers among a set of technical practices recommended by the CRISL to the growers. Regarding the type of farming system, the majority of the farmers had a cultivation with intercrops, in large scale or as additional crops in small scale in addition to coconuts trees and 34\% had only coconuts in their estates. For the others, $16 \%$ had a mix of livestock, intercrops and coconuts and the minority had only livestock and coconut trees. (Figure 2)

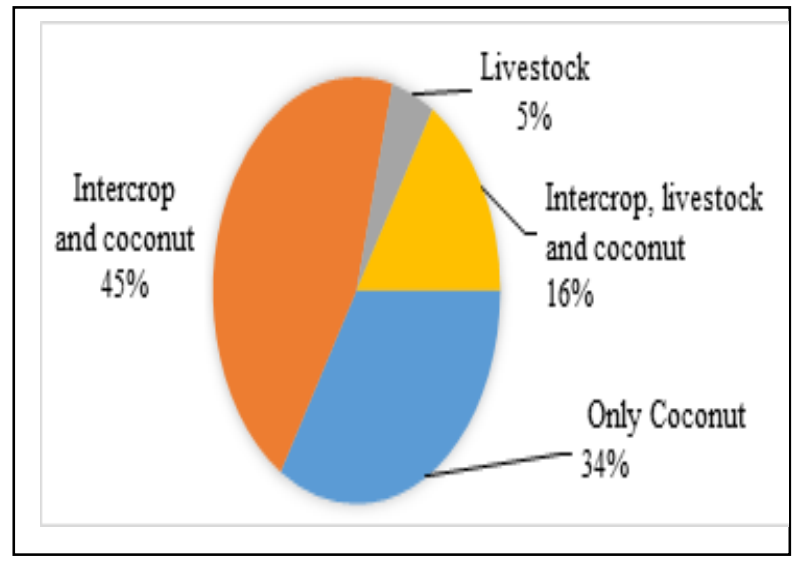

Figure 2. Type of farming system $(\mathrm{N}=62)$

Among the farmers who cultivated intercrops, the majority $(62.2 \%)$ had a combination of several intercrops. The pepper was cultivated by $54 \%$ of the growers and the banana by $40 \%$ of the respondents. Concerning livestock, most of the farmers $(77 \%)$ had only one type of animal, cattle dominated by $61 \%$ of the growers.

Regarding to the interval time between two picks, most of the farmers $(56.7 \%)$ harvested nuts with two months intervals, $31.7 \%$ one month and a half and only $6.6 \%$ an interval of one month.

For the soil moisture conservation, the majority of the respondents improved the soil moisture by using mulching. Mulching is the covering of the soils around the manure circle by organic substances such as coconut husks only, dried coconut fronds, coir dusts, weed thrash etc. The farmers used burial of coconut husks as a moisture conservation practice along with mulching than only burial of coconut husks. $30.1 \%$ of the growers did not use any technique to improve the soil moisture. (Figure 3)

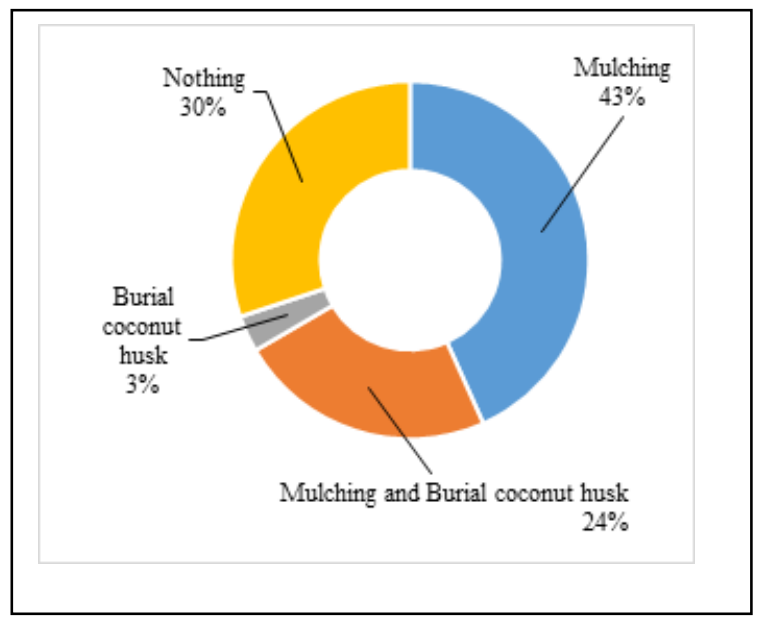

Figure 3. Techniques to improve soil moisture

It was revealed that mulching was used by $67 \%$ of the grower's in their estate and burial of coconut husks in $26.7 \%$. According to the data, most of the time the mulching was done with coconut fronds (62.5\%) and coconut husks (57.4\%). The weed trash was used in $47.5 \%$ of the estates and the fallen leaves in $23.3 \%$. For the burial technique, $56.4 \%$ of the farmers buried with pits between coconut palms. 
$\underline{\text { Relationship between the practices used, the land extent and the yield }}$

Table 2. Spearman's correlation between practices, yield and land extent

\begin{tabular}{|l|ll|c|}
\hline \multicolumn{1}{|c|}{ Practices } & \multicolumn{2}{c|}{ Yield } & \multicolumn{2}{c|}{ Land extent } \\
\hline Type of farming system & $-0.270^{*} \quad(\mathrm{~N}=57)$ & $0.387^{* *} \quad(\mathrm{~N}=59)$ \\
\hline Interval time between two picks & -0.20 & $(\mathrm{~N}=56)$ & $-0.371^{* *}(\mathrm{~N}=57)$ \\
\hline Soil moisture conservation & $0.143 \quad(\mathrm{~N}=54)$ & $-0.401^{* *}(\mathrm{~N}=56)$ \\
\hline Fertilizer application & $0.066 \quad(\mathrm{~N}=55)$ & $-0.38 \quad(\mathrm{~N}=57)$ \\
\hline Weed management & $0.207 \quad(\mathrm{~N}=54)$ & $0.193 \quad(\mathrm{~N}=57)$ \\
\hline
\end{tabular}

*. Correlation is significant at the 0.05 level (2-tailed).

**. Correlation is significant at the 0.01 level (2-tailed).

Type of farming system was significantly related with the yield and the land extent of the estates (Table 2). However, it is negatively related with the yield. In fact, for the land with only coconut cultivation, the yield is higher than estates with intercrops and livestock. It may presume that intercrops and livestock compete with coconut cultivation for the nutrients and water sources, but this warrants further investigation with bigger sample number. On the other hand, yield was positively related with the land extent: the growers which used intercrops and livestock needed more space for this kind of cultivation or animal husbandry.

Interval time between two picks was significantly and negatively correlated with the land extent. We can see that the large estates are very specialized in coconut cultivation. Moreover, they have labour during all the year to harvest coconuts in the advised time: one month. (Table 2)

For the smallest estates, the interval time between two picks is higher. In fact, the level of education is significantly and positively related with the farm size (Spearman's rho $=0.289^{* *}$ ). The growers of this type of farm have not a high level of education. Moreover, the time spent on farming is significantly and positively related with the education (Spearman's rho $=0.341^{* *}$ ) (Herath et al., 2008). So, it can be assumed that when the farm size is small, the time spent of farming is low. Indeed, the harvest in this kind of farm is only realized if farmers and labours are available at the right moment.
Soil moisture conservation is significantly and negatively related with land extent. (Table 2 ) It means that the soil moisture conservation practices are mostly applied in large estates as it was shown in the published article by Jayalath, et al. (2010). Moreover, the average surface of the estates without any technique to improve the soil moisture was 1.7 acres $(\mathrm{SD}=1.4)$. So, we can observe that the improvement of soil moisture is not used very often for the small estates. Indeed, as shown earlier, the famers with small estates don't spend enough time for farming. It can be assumed that moisture conservation practices are not applied by small scale farmers because of the time it requires and that their main income is not the coconut cultivation.

One of the practices studied with the questionnaire was the fertilizer application. In this study, the results were not significant (Table 2 ) regarding the yield and the land extent but about the practices: $55 \%$ of the farmers used Adult Palm Mixture, 20\% applied organic fertilizer and $13.3 \%$ used direct method. Otherwise, $11.7 \%$ of the growers did not apply fertilizer. The average of their estate was 2.1 acres $(\mathrm{SD}=3.87)$. For the dolomite application, which is a practice to provide $\mathrm{Mg}, 66.7 \%$ of the farmers followed the instructions of the CRI because they applied $1 \mathrm{Kg}$ of dolomite per tree per year. According to a study the nut yield can be increased by $40 \%$ by the adoption of CRISL recommended technologies (Liyanage, 1999). 
Effects of the information sources to the enhance of the farmer's skills

Table 3. Spearman's correlation between the ways to improve the knowledges, yield and land extent

\begin{tabular}{|l|c|c|}
\hline Improvement of knowledges & Yield & Land extent \\
\hline Attending training programs & $-0.079 \quad(\mathrm{~N}=57)$ & $-0.549^{* *}(\mathrm{~N}=59)$ \\
\hline Information sources & $-0.061 \quad(\mathrm{~N}=55)$ & $-0.350^{* *}(\mathrm{~N}=57)$ \\
\hline
\end{tabular}

**. Correlation is significant at the 0.01 level (2-tailed).

Attending training programs or information taken from various specialised sources revealed not to be significantly correlated with the yield. However, both are significantly and negatively related with land extent. We can observe that the owners of large estates attended training programs during five last year. It can be assumed that training is very useful for the growers with large land extent to manage their estates well. Indeed, training programs play a vital role in technology adoption decisions providing farmers with the technical knowledge necessary for the selection of appropriate crop management practices (Prudent et al, 2017).

Moreover, when look at the information sources for coconut, it can be seen that the CRISL is a major source for the farmers with large estates. Indeed, growers need specific advices to manage their coconut lands. On the other hand, it looks like that the growers with small land extent do not really need to seek the advice from CRISL or other extension services. For them, talking with input dealers or neighbouring farmers are sufficient for their cultivation.

Satisfaction about applying interval time, intercrops, weed control or pest control are not significantly related with the yield. In fact, the measure of satisfaction that a practice gives to the yield is strongly dependant of farmers. Farmers can have a bad yield and can observe that if they donot apply their practices, the yield could be worst. In that case, the yield depends of other factors. On another hand, yield can be very high, but farmers can find that their practices could be improved to reach the potential of their field to increase the yield again.

Table. Spearman's correlation between scales of satisfaction about practices, yields and land extent

\begin{tabular}{|l|c|c|}
\hline $\begin{array}{c}\text { Scales of } \\
\text { satisfcation }\end{array}$ & Yield & Land extent \\
\hline $\begin{array}{l}\text { Interval time } \\
\text { application }\end{array}$ & $0.136(\mathrm{~N}=51)$ & $0.170(\mathrm{~N}=51)$ \\
\hline $\begin{array}{l}\text { Intercrops } \\
\text { application }\end{array}$ & $-0.294(\mathrm{~N}=25)$ & $0.403 *(\mathrm{~N}=26)$ \\
\hline $\begin{array}{l}\text { Wed control } \\
\text { application }\end{array}$ & $-0.134(\mathrm{~N}=52)$ & $0.304 *(\mathrm{~N}=53)$ \\
\hline $\begin{array}{l}\text { Pest control } \\
\text { application }\end{array}$ & $0.071(\mathrm{~N}=37)$ & $-0.109(\mathrm{~N}=35)$ \\
\hline
\end{tabular}

However, it can be observed that intercrops and weed control applications are positively and significantly correlated with the land extent. Indeed, farmers with large estates found that intercrops improve the yield of coconut trees. Moreover, according to the table 2 , intercrops are more suitable for large estates. Small estates did not apply weed control or did not find an improvement of this practice to the yield on their scale. But for large estates, weed control was a very important practice to improve the yield of coconut fields. It can be said that large estates are very specialized, so each technique needs to be applied correctly to avoid even a small loss of yield. 


\section{Conclusion}

As the study shows, the most frequent agronomic practices that are used by farmers have been clearly identified. Concerning the type of farming system, most of the growers are having intercrops between the coconut trees, in large or even small scale, even if the yield is lower and it needs more space, according to the study. Between two picks, farmers are applying an interval of two months. In fact, majority of them have small land extents and they do not spend a lot of time for coconut cultivation. Concerning, the improvement of soil moisture, the most used practice is mulching followed by nothing applied (mainly used by small farmers) and a mix of mulching and burial of coconut husks. To improve their yield, mostly applied fertilizer type is "Adult Palm Mixture" (APM) recommended by CRISL. This practice is followed by organic manure and direct fertilizer method. Finally, the study shows that farmers with large estates are the most involved to follow training programs and apply the recommendations given by the CRISL.

\section{Limitations of the Study}

Only coconut growers from three districts in "Coconut Triangle", Sri Lanka were chosen to collect the data. Thus, it has faced the limitation of location-feedbacks. The sample size of this study was just 62 respondents. Therefore, the large sample size would be discovered extraordinary, is seen as another limitation of this study. Furthermore, to gather quantitative data, close ended questionnaire was implemented and it may force growers to pick a particular response which was not represent their actual output. Some kind of biasness could be occurred in the study, because of the selfadministered questionnaire that was used. Therefore, there was a possibility to choose the correct answer or any other response that reflect their preference rather than the real practice.

\section{Acknowledgement}

The first two authors from the University de Lorraine, France greatly appreciate the management of the Coconut Research Institute of Sri Lanka for the opportunity given for them to conduct their internship at various research divisions of the institute and for providing all the facilities needed for them to carry out the study. Dr. Chaminda Herath and Mr. Rusitha Wijekoon and the staff of the Technology Transfer Division of the Institute are also gratefully acknowledged for this piece of study conducted under their guidance. Further, Dr. Lalith Perera of CRISL is exceedingly acknowledged particularly for arranging and coordinating this internship.

\section{References}

Department of Census and Statistics. (2018). General Report, Economic Census 2013/14, Agricultural Activities, Sri Lanka. ISBN - 978-955-702-100-3.

Herath, C.S., Chandrarathna, J.P.T.R. and Abewickrama, S.W.R.K. (2015). Major problems encountered by the coconut growers who visit coconut technology park of coconut research institute of Sri Lanka. COCOS, 20, 1-8, http://doi.org/10.4038/ cocos.v20i0.5793.

Jayalath, K.V.N.N., Pathiraja, P.M.E.K., Jayasinghe-Mudalige, U.K. and Fernando, M.T.N. (2010). An empirical investigation on the effect of size of land of coconut cultivation in Sri Lanka on its productivity. COCOS, 19(2): 67-75, http://cri.nsf.ac.lkand http://asiajol.info/index.php

Liyanage M. de S. (1999). A guide to scientific cultivation and management of coconut, Nuegoda, Sri Lanka. ISBN - 955-96945-02. 
Pathmeswaran, C., Lokupitiya, E., Waidyarathne, K.P. and Lokupitiya, R.S. (2018). Impact of extreme weather events on coconut productivity in three climatic zones of Sri Lanka. European Journal of Agronomy.96, 47-53, http://doi.org/ 10.1016/ j.eja.2018.03.001.

Prudent, P., Loko, S., Deybe, D., Vaissayre, M. (2007). Factors limiting the adoption of IPM practices by cotton farmers in Benin: a participatory approach. Exp. Agr., 43, 113-124.

Technology Transfer Division, CRISL. (2018). About the Coconut Research Institute.

Technology Transfer Division, CRISL. (2018). About the Coconut Research Institute, CRISL, Bandirippuwa Estate, Lunuwila.

[Note: This study was conducted by two French university students; Mr. Baptiste Legrandand Miss. Angélique Perrautas a part of their internship at the Coconut Research Institute of Sri Lanka.] 